\title{
Interleukin-6 in cardiac surgery
}

\author{
SHI-MIN YUAN 1 \\ HUI-ZHEN LIN ${ }^{2}$ \\ 1 Department of Cardiothoracic Surgery, Department \\ of Cardiothoracic Surgery, The First Hospital of \\ Putian, Teaching Hospital, Fujian Medical University, \\ 389 Longdejing Street, Chengxiang District, Putian \\ 351100, Fujian Province, People's Republic of China

\section{Department of Clinical Laboratory, The First} \\ Hospital of Putian, Teaching Hospital, Fujian Medical \\ University, Putian 351100, Fujian Province, People's \\ Republic of China.
}

\section{Correspondence:}

Shi-Min Yuan, MD, PhD,

E-mail:shiminyuan@126.com

Key words: cardiac surgical procedures; inflammation; interleukin-6
Received January 28, 2016.

Revised April 02, 2017.

Accepted April 12, 2017.

\section{Abstract}

Background and Purpose: Interleukin (IL)- 6 is a multi-functional proand anti-inflammatory cytokine, and it has been a reliable biomarker of cardiac function status and myocardial damage. However, the characteristics of IL- 6 expressions in the cardiac surgical patients have not been comprehensively described. The purpose of this review is to present the current knowledge on the role of IL- 6 in the field of cardiac surgery.

Materials and Methods: Medical literature of IL-6 in cardiac surgical disorders of recent 3 decades were carefully collected as studying materials, and comprehensively reviewed and analyzed.

Results: Plasma IL-6 was significantly elevated 1 hour and peaked 3-6 hours after the start of cardiopulmonary bypass with a gradual decrease constant maintenance thereafter. No significant differences were found between patients with biological and mechanical heart valve replacements between on-poump and off-pump coronary artery bypass, or between cyanotic and acyanotic congental heart patients. The elevation of IL- 6 was higher in mitral valve replacement than in coronary artery bypass grafting patients and in non-heart transplantation than in heart transplantation patients. Il-6 was involved in the pathogenesis of pulmonary artery hypertension and infective endocarditis, and predicted adverse cardiac events, such as coronary graft occlusion, aortic dissection progression and cardiac myxoma recurrence.

Conclusions: In cardiac surgical patients, the expression of IL- 6 reflects the inflammatory situation of the patients and also predicts their prognosis. The higher elevation of IL- 6 in mitral valve replacement and in non-heart transplantation might be attributed to cardiotomy suction, and to lack of sterioid use. Early administrations with steroid, $\alpha_{2}$-adrenergic agonists, incretin hormones, or ischemic conditioning could reduce the inflammatory response and prevent from pertinent postoperative complications. Anesthetic agents and technique of choices may also reduce immune reactions and lower circulating cytokines. Extracorporeal IL- 6 removal facilities have been successfully applied in clinical practice. The potential alternative therapies with IL-G antibodies might be further developed and used in such patients for preventing myocardial apoptotic processes.

\section{INTRODUCTION}

Tnterleukin (IL)-6 is a multi-functional pro- and anti-inflammatory 1 cytokine, and it has become a reliable biomarker of cardiac function status and myocardial damage (1). IL- 6 acts its biological functions via 2 signaling pathways: classic and trans-signaling pathways. The classic signaling mediates regenerative or anti-inflammatory activities of IL-6, whereas trans-signaling mediates pro-inflammatory processes. From the cellular level, IL- 6 is produced principally by activated T lymphocytes 
in the presence of macrophages or by macrophages alone, and secondarily by endothelial cells and fibroblasts. From the organ level, the heart would be a major source of IL- 6 production as IL-6 levels were much higher in the coronary sinus blood than in the arterial blood (2).

IL-6 plays an important role in the pathogenesis of coronary artery disease (3). In animal experiments, IL-6 was illustrated to be an inducer of myocyte hypertrophy, and targeted deletion of the IL- 6 gene would not affect infarct size or left ventricular remodeling. Consequently, combination therapy involving IL- 6 and soluble IL- 6 receptor might inhibit cardiomyocyte apoptosis and reduce myocardial infarct size (4). Moreover, patients with persistently elevated IL-6 levels demonstrate symptomatic congestive heart failure, larger end-diastolic and endsystolic diameters, increased left atrial size and a worse in-hospital outcome following admission with unstable angina (5). In patients with paroxysmal atrial fibrillation, IL- 6 concentration was elevated significantly and decreased gradually after recovery to sinus rhythm (6). Furthermore, IL- 6 has also been recognized to be involved in the postinterventional and postoperative complications. The roles of IL- 6 expressions and IL- 6 gene polymorphism in the cardiac surgical patients have not been comprehensively described even though deliberations on respective disorders or operations were narrated. The aim of this review is to present the current knowledge on the role of IL-6 in the field of cardiac surgery.

\section{IL-6 IN CARDIAC SURGERY}

\section{Cardiopulmonary bypass (CPB)}

IL-6 is elevated in the conditions of surgical trauma, increased shear stress, ischemia-reperfusion injury and hypothermia (1). Cardiac operations under CPB induce local and systemic inflammatory responses, thereby leading to multiple organ failure as a consequence of microcirculation disturbances. CPB activates inflammatory response by three mechanisms: contact activation, ischemia-reperfusion injury and endotoxemia. The triggering factors involved in the inflammatory process may be surgical procedure, duration of the ischemia and reperfusion in the heart, exposure of blood to the extracorporeal circuit, or release of endotoxin (7). Usually, plasma IL-6 was significantly elevated 1 hour and peaked 3-6 hours after the start of $\mathrm{CPB}$ with a gradual decrease constant maintenance thereafter (8). Plasma IL-6 increased within a few hours after the completion of $\mathrm{CPB}$ and lasted up to 24 hours. Plasma IL-6 increased during CPB comparing to baseline $(42.1 \pm 2.9 \mathrm{pg} / \mathrm{mL}$ to $71.1 \pm 6.0 \mathrm{pg} / \mathrm{mL}, p<0.05)$. The maximum concentration of IL- 6 occurred before skin closure $(116.6 \pm 8.3 \mathrm{pg} / \mathrm{mL})$ significantly higher than control (9). The mechanism was considered to be circulating inflammatory cells activated by exposure to the extracorporeal circuit and moderate hypothermia. In contrast, the heart transplantation patients who received the immunosuppressive drugs, such as azathioprine and meth- ylprednisolone, during the operation showed less elevated circulating IL-6 levels, and clinical observations revealed that early steroid administration before $\mathrm{CPB}$ could reduce the inflammatory response and enhance the release of IL-10 (10).

\section{Coronary artery bypass grafting (CABG)}

IL-6 levels did not differ between on- and off-pump CABG patients. The peak values of IL- 6 were found at the time protamine use in both groups, and then the IL- 6 levels decreased gradually and recovered to baseline level at 30 day after operation (Figure 1) (11). IL-6 levels in CABG patients may predict, 1) complement system activation, 2) postoperative inflammatory reaction, and 3) late cardiovascular events, such as occluded bypass grafts (12). Hedman et al. (12) proposed a cut-off value of IL-6 of $3.8 \mathrm{pg} / \mathrm{mL}$, a level above which in CABG patients might predict the adverse events.

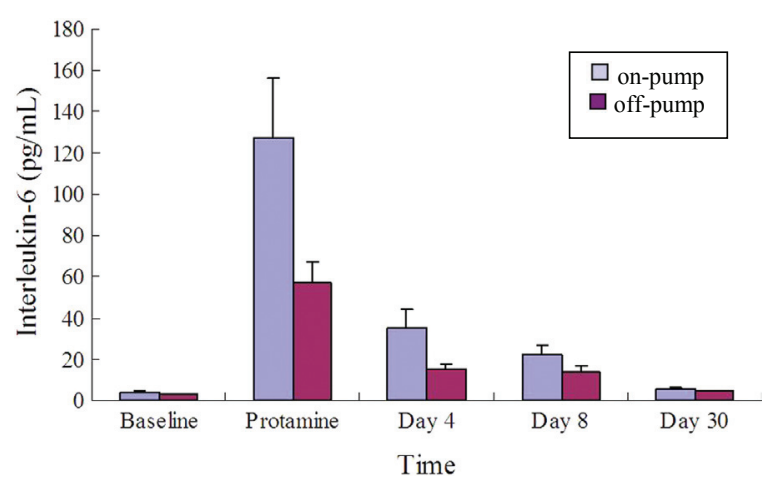

Figure 1. A comparison of plasma interleukin- 6 levels between onand off-pump coronary artery bypass patients (11).

It also illustrated that the IL-6 levels in patients receiving minimally invasive direct coronary artery bypass were significantly lower in the first 8 postoperative hours than those of the patients receiving conventional CABG, but a steady increase was observed during the postoperative course. After 24 hours, the level was comparable to that in the CABG group and significantly higher compared with the preoperative control (13). Some inflammatory markers (IL-1, IL-6 and some leukocyte subsets) showed similar kinetics in both on- and off-pump CABG operations, whereas other cytokines (tumor necrosis factor- $\alpha$, IL-8, IL-10 and elastase) showed earliest and highest peak levels. In brief, the inflammatory reactions occurring in the postoperative course of CABG were unrelated to the surgical strategy adopted, owing to the inflammatory reactions limited to the final phases of the operation (11).

\section{Heart valve operation}

A retrospective analysis demonstrated that no differences were found in circulating IL- 6 levels between the types of heart valve prostheses (mechanical or biological) 
and implant sites (mitral or aortic postion) (Figure 2) (14). A comparative study demonstrated that the serum IL-6 increased immediately after aortic crossclamp and reached its peak at the end of surgery in both CABG and heart valve groups. Serum IL- 6 levels at the end of surgery and 24 hour after surgery were significantly higher in the valve group than in the CABG group $(123.9 \pm 21.7 \mathrm{pg} / \mathrm{mL} v$ s. $79.7 \pm 10.4 \mathrm{pg} / \mathrm{mL}, p=0.049 ; 113.6 \pm 25.0 \mathrm{pg} / \mathrm{mL}$ vs. 39.9 $\pm 11.5 \mathrm{pg} / \mathrm{mL}, p=0.006$ ). It was explained as cardiotomy suction might be directly and specifically related to increased serum IL-6 levels after valve surgery (15).

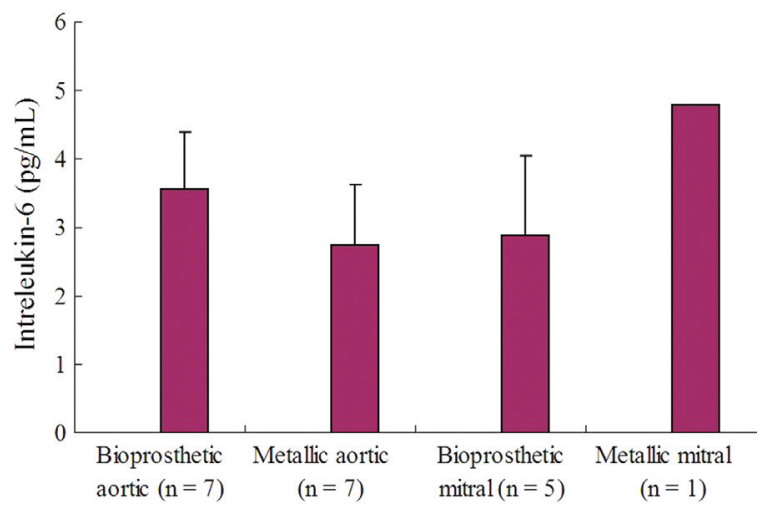

Figure 2. A comparison of plasma interleukin- 6 levels between the types of heart valve prostheses and implant sites (14).

\section{Infective endocarditis}

The circulating IL-6 levels were noted to be increased in all patients with infective endocarditis $(16.2 \pm 15 \mathrm{pg} /$ $\mathrm{mL}$ ), and significantly higher than those of the control (16). The IL-6 elevation was especially noted in patients with positive blood cultures, and a decrease of IL-6, during the whole treatment period, in comparison with that on admission, thereby reflecting the inflammatory proto$\mathrm{col}$ in the process of infective endocarditis (17). However, differences of circulating IL-6 levels in infective endocarditis patients between different pathogens were not evaluated.

\section{Congenital heart defect repair}

The circulating IL- 6 levels were found to be higher in both cyanotic $(16.2 \pm 6.9 \mathrm{pg} / \mathrm{mL})$ and acyanotic patients with congenital heart disease $(13.6 \pm 5.8 \mathrm{pg} / \mathrm{mL})$ when compared with the control, but the change of IL- 6 was more pronounced in the cyanotic patients (18). In such patients, the circulating IL- 6 on postoperative day (POD) 1 increased to $271 \pm 68 \mathrm{pg} / \mathrm{mL}$ from a preoperative baseline level of $46 \pm 12 \mathrm{pg} / \mathrm{mL}$, and declined on PODs 2 and 3 , but insignificantly different from the baseline. Patients with single ventricle anatomy had the highest circulating IL-6 level on POD 1 as $629 \pm 131 \mathrm{pg} / \mathrm{mL}$, which was closely related to the elongation of CPB time to $106 \pm 23$ minutes (19). Significant correlations of postoperative se- rum IL- 6 and IL-8 with increased inotropic requirements and reduced arterial oxygen tension 2 hours after $\mathrm{CPB}$ were also noted (20).

\section{Pulmonary artery hypertension (PAH)}

Patients with idiopathic PAH have been noted an increased circulating and pulmonary tissue IL- 6 expressions (21). IL-6 may play a pathologic role through inflammation, cellular proliferation, interaction with bone morphogenetic protein pathways, decreasing prostacyclin and induction of the production of other nediators, such as serotonin, endothelin-1 and vascular endothelial growth factor (VEGF). Experimental studies demonstrated that hypoxic and monocrotaline-induced $\mathrm{PAH}$ was associated with increased IL-6 levels (22). Overexpression of IL-6 in the mouse lungs resulted in increased pulmonary vascular resistance in the context of the pathological lesions similar to that seen in patients with $\mathrm{PAH}$, including muscularization of the distal arterioles, plexogenic pulmonary arteriopathy and periarteriolar infiltration of $\mathrm{T}$ cells. These findings indicated that IL- 6 directly or indirectly promoted proliferation of both smooth muscle and endothelial cells, triggering vascular smooth muscle cell proliferation through upregulated expression of VEGF and its receptor VEGF receptor II, through which it promoted the development and progression of pulmonary vascular remodeling (21). Stimulated by IL-6, pulmonary artery endothelial cells form smooth concentric multilayers, leading to thickening of the intimal wall, narrowing the distal arteriolar lumen and forming a plexiform lesion. IL-6 might result in distal extension of the smooth muscle into the small peripheral pulmonary arteries at the level of the acinous, where the medial wall might become further hypertrophied with the added insult of hypoxia (23). IL-6-induced VEGF expression might also indirectly increase the number of pulmonary artery smooth muscle cells by transforming into smooth muscle-like cells. Pulmonary endarterectomy is a potential curative treatment method for patients with chronic thromboembolic pulmonary hypertension. Plasma IL-6 in such patients peaked at 12 hours after termination of CPB and then decreased and recovered to baseline at 72 hours. Plasma IL-6 concentrations correlated inversely with cardiac index at the time of separation from CPB. Similarly, IL-8 concentrations correlated significantly with cardiac index at the same time. However, no significant relation was found between postoperative cytokine levels and mean pulmonary artery pressure or pulmonary vascular resistance (24).

\section{Aortic aneurysm/dissection}

Aortic aneurysm formation is an inflammatory process according to contemporary theories. Many studies have identified associations between pro-inflammatory cytokines and abdominal aortic aneurysm formation, expansion, or rupture. IL- 6 and tumor necrosis factor- $\alpha$ are 
major inflammatory cytokines and have multiple important effects on human vascular pathophysiology. Research showed IL- 6 concentrations were higher in acute aortic dissection than that in hypertension and healthy controls (25). Juvonen et al. (26) reported that IL-6 concentration was similar irrespective of dimensions of abdominal aorta aneurysms and presence of thrombus. Significant elevations of IL- 6 and tumor necrosis factor- $\alpha$ levels were also detected in patients admitted at the acute phase of type A aortic dissection when compared with the other 2 control groups. However, no significant differences were noted between the chronic type A aortic dissection and hypertension patients. These findings accordingly confirmed that inflammation was closely involved into the pathogenesis of hypertension-induced aortic wall injury and the development of aortic dissection. Secretion of IL-6 occurred during open surgery as well in the endovascular treatment due to ischemia-reperfusion injury and after exposure of leukocyte to prosthetic materials. The plasma IL- 6 increased on POD 1 of stent implantation of abdominal aorta (27). Increased IL-6 in supernatant of thrombotic contents of abdominal aortic aneurysms might explain the inflammatory response during endovascular repair (28). The aneurysm dimensions of the ascending and descending aorta did not correlate with serum C-reaction protein and IL-6. There was a strong linear correlation between the aneurysmal size and the C-reaction protein/IL-6 ratio for values above 0.8 . The mean serum IL-6 levels of the ascending and descending aortic aneurysms were 7.58 and $6.86 \mathrm{pg} / \mathrm{mL}$, respectively, with no significant difference (29). A recent study demonstrated a higher IL-6 level in acute aortic dissection than that in hypertension and healthy controls, no significant difference found between with and without endovascular treatment, and or between acute and chronic aortic dissection patients (30). A serological study supported the notion that endovascular repair might be rather less aggressive as evidenced by insignificant inflammatory modulations. The longer stent grafts were found to be associated with significant changes of IL-1 $\beta$ and IL-6 than shorter ones (31). This phenomenon was interpreted as stent graft deployment might definitely covered portions of spinal arteries, which might cause more severe hypoperfusion of the spinal cord by longer stents, thereby increasing the release of ILs in spite of the lack of clinical signs of paraplegia (31). An elevated circulating IL-6 has been proved to be a predictive risk factor of mortality in elderly patients with cardiovascular disorders. However, the circulating IL- 6 changes in aortic aneurysmal patients receiving endovascular treatment remain to be clarified.

\section{Cardiac myxoma}

Various cytokines and growth factors including IL-6 were involved in tumor growth and angiogenesis. In one series of 37 cases of myxoma, $74 \%$ showed expression of IL-6 (32). Cardiac myxomas produce IL-6, which is a possible explanation for the inflammatory and immune features observed in the patients. The circulating IL-6 levels directly correlated the tumor size, i.e., the number of IL-6-producing cardiac myxoma cells (33). A recent study demonstrated that circulation IL-6 level directly correlated with the tumor size, or with the recurrence of the tumors regardless of tumor size. According to the study, the overproduction of IL- 6 by cardiac myxomas should be responsible for the constitutional symptoms and immunologic abnormalities in the patients, and might also serve as a marker of recurrence (34). The constitutional symptoms of cardiac myxoma patients for example, the onset fever of unknown origin of cardiac myxoma, might be mediated by IL-6 (35). Myxoma is highly aggressive due to IL- 6 production irrespective of the tumor size, and the serum IL- 6 level decreased rapidly after the cardiac myxoma resection and it remained in the normal range, but it would be elevated again when recurrent $(34,35)$. Therefore, IL-6 might also play a role in inducing the activation and proliferation of secondary foci in the event of multifocal recurrence.

\section{Heart transplantation}

A comparative study revealed that plasma levels of IL6, IL- 8 and IL-10 were increased in patients undergoing heart transplantation at the time of reperfusion, whereas IL-6 levels were higher in the non-heart transplantation group 24 hours after reperfusion (36). This inter-group disparity was considered to be a result of an absence of immunosuppressive therapy in the non-heart transplantation group (36). Research works also disclosed that the ischemic or CPB duration correlated circulating IL- 6 or IL-8 levels, indicating the important role of ischemia duration that played in the inflammatory reactions. IL-6 elevation in the donor hearts might be due to the endogenous norepinephrine after brain death or to the exogenous norepinephrine administration to the donors. IL-6 can be produced from leukocytes, endothelial cells and vascular smooth muscle cells in vitro and has recently been detected in cardiac myocytes. Messenger ribonucleic acid of IL-6, IL-6 receptor and gp130 were observed to be strongly expressed in all chambers of donor hearts, whereas right ventricles of control patients did not express them. This phenomenon might explain the close relationship between elevated IL- 6 levels and acute cardiac allograft dysfunction. An upregulation of IL-6 receptor in the donor heart after brain death was likely to illustrate that circulating IL- 6 , generated either by the donor heart or by the recipient due to advanced heart failure or after cardiac surgery, exerted its negative inotropic effects on the donor heart (37).

\section{Left ventricular assist device (LVAD)}

Cardiac content and expression of IL- 6 might reflect an in situ inflammation due to the local infiltration of the inflammatory cells. Cardiac levels of IL-6 were less as- 
sociated with the hemodynamic status of LVAD recipients, and did not predict to risks. In a cohort of LVADcandidates, only patients with preoperatively elevated IL-6 levels, particularly $>8.3 \mathrm{pg} / \mathrm{mL}$, were more susceptible to serious complications, such as severe multiple organ failure (38). At the time of LVAD implantation, the mean serum IL-6 level was 33.6 \pm 9 (range, 1.07-106.9) $\mathrm{pg} / \mathrm{mL}$. After a mean duration of LVAD support of $64 \pm$ 8.4 days, IL- 6 levels decreased to $11.3 \pm 4 \mathrm{pg} / \mathrm{mL}$. The patient with an infected device at time of explant had an increase in both IL- 6 and tumor necrosis factor- $\alpha$ levels (39).

\section{IL-6 GENE POLYMORPHISM}

The IL-6 polymorphism might influence the circulating IL-6 levels and functioning activity of IL-6 protein and might indicate the postoperative outcomes of the patients (40). IL-6 gene G-174C polymorphism did not correlate with the number of stenosed coronary vessels. However, IL- 6 gene G-174C polymorphism significantly associated with the prognosis of coronary patients: there were more cardiovascular events (revascularization, myocardial infarction and death) in the CC genotype carriers than in the GG/GC genotype carriers. There was no significant difference between patients with coronary revascularization (percutaneous transluminal coronary angioplasty with or without stent implantation and (or) CABG) and those without the need of revascularization. In addition, smokers with the CC genotype were an increased mortality risk compared to GG/GC carriers (41).

\section{RISK FACTORS OF IL-6 ACTIVITION}

The risk factors triggering IL- 6 activities may include increasing age (in particular older age $>70$ years), obesity, atherosclerosis, diabetes (42), hepatic and renal dysfunction, high postoperative oxygen consumption and adrenaline infusions (43), etc.

\section{IL-6 REMOVAL}

Excessive circulating cytokines can be harmful. The cytokine antibodies to reverse hypercytokinemia seemed to be a vain in keeping the homeostatic balance (44). Anesthetics may reduce immune reactions and lower circulating cytokines including IL-6, by reducing the activity of adrenergic receptor, suppressing of inducible nitric oxide synthase/nitric oxide biosynthesis, and inhibiting nuclear factor- $\kappa \mathrm{B}$ activation (45). The representative anesthetics include desflurane, propofol, fentanyl, remifentanyl, kesmine (44), sevoflurane (43) and thiopental (46), etc. Early steroid administration before $\mathrm{CPB}$ can reduce the inflammatory response. Dexmedetomidine, an $\alpha_{2}$ adrenergic agonists, was considered an anti-inflammatory agent for preventing inflammatory reaction to cardiac surgery with substantial efficacy and safety (47). Gluca- gon-like peptide-1, an incretin hormone, was found to reduce circulating IL-6 levels in humans (48). Ischemic conditioning (pre and post) is a potential protective measure for prolonged ischemia and associated cytokine release (43). Plasma filtration was successful in cytokine removal but was associated with albumin loss. Hemodiafiltration with filters was not very encouraging due to a lower removal degree. Extracorporeal support systems may serve as cytokine removal facilities (44). Polymyxin B-immobilized cartridge has been successfully used in endotoxin elimination (49). CytoSorb ${ }^{\varpi}$ is effective in reducing postoperative systemic inflammatory response syndrome. Hemoadsorption by using CytoSorb ${ }^{\circledR}$ (CytoSorbents Corporation, USA) is a novel technique for removal of cytokines including IL-6, tumor necrosis factor and IL-10, when unresponsive to blood purification techniques. With the use of CytoSorb ${ }^{\circledR}$, not only circulating IL-6 was removed, but inotropic support was also reduced and no complications were found (50). Recently, high cut-off hemofilters were proved to be effective in removing many cytokines including IL-6 in septic shock patients.

\section{CONCLUSIONS}

In cardiac surgical patients, the expression of IL-6 reflects the inflammatory situation of the patients caused by surgical trauma and $\mathrm{CPB}$ and it also predicts the prognosis of these surgical patients. IL- 6 could be a reliable biomarker of cardiac surgery. Early administration with steroid, $\alpha_{2}$-adrenergic agonists, incretin hormones, or ischemic conditioning before $\mathrm{CPB}$ may reduce the inflammatory response and prevent from certain postoperative complications. Anesthetic agents and technique of choices may also reduce immune reactions and lower circulating cytokines. Extracorporeal IL-6 removal facilities have been successfully used in clinical practice. According to the kinetic features of the cytokines including IL-6, potential alternative therapies with IL- 6 antibodies might be further developed and used in these patients to inhibit myocardial apoptotic processes.

\section{REFERENCES}

1. AI AL, HALL D, BOLLING SF 2012 Interleukin- 6 and hospital length of stay after open-heart surgery. Biol Psych Psychopharmacol 14: 79-82

2. WAN S, DESMET JM, BARVAIS L, GOLDSTEIN M, VINCENT JL, LECLERC JL 1996 Myocardium is a major source of proinflammatory cytokines in patients undergoing cardiopulmonary bypass. J Thorac Cardiovasc Surg 112: 806-11. https://doi.org/10.1016/S0022-5223(96)70068-5

3. KANDA T, TAKAHASHI T 2004 Interleukin- 6 and cardiovascular diseases. Jpn Heart J 45: 183-93. https://doi.org/10.1536/jhj.45.183

4. KOBARA M, NODA K, KITAMURA M, OKAMOTO A, SHIRAISHI T, TOBA H, MATSUBARA H, NAKATA T 2010 Antibody against interleukin- 6 receptor attenuates left ventricular remodelling after myocardial infarction in mice. Cardiovasc Res 87: 424-30. https://doi.org/10.1093/cvr/cvq078 
5. BIASUCCI LM, LIUZZO G, FANTUZZI G, CALIGIURI G, REBUZZI AG, GINNETTI F, DINARELLO CA, MASERI A 1999 Increasing levels of interleukin (IL)-1Ra and IL-6 during the first 2 days of hospitalization in unstable angina are associated with increased risk of in-hospital coronary events. Circulation 99: 2079-84. https://doi.org/10.1161/01.CIR.99.16.2079

6. NEGREVA MN, GEORGIEV SJ, PENEV AP 2015 Cytokine Interleukin-6 in patients with paroxysmal atrial fibrillation. Int J Pharm Med Res 3: 16-20

7. CASEY LC 1993 Role of cytokines in the pathogenesis of cardiopulmonary-induced multisystem organ failure. Ann Thorac Surg 56 (Suppl 5): S92-6.

https://doi.org/10.1016/0003-4975(93)91143-B

8. MENG QH, ZHU S, SOHN N, MYCYK T, SHAW SA, DALSHAUG G, KRAHN J 2008 Release of cardiac biochemical and inflammatory markers in patients on cardiopulmonary bypass undergoing coronary artery bypass grafting. J Card Surg 23: 681-7. https://doi.org/10.1111/j.1540-8191.2008.00701.x

9. ABE K, NISHIMURA M, SAKAKIBARA T 1994 Interleukin-6 and tumour necrosis factor during cardiopulmonary bypass. Can J Anaesth 41: 876-7. https://doi.org/10.1007/BF03011610

10. WAN S, DESMET JM, ANTOINE M, GODLMAN M, VINCENT JL, LECLERC JL 1996 Steroid administration in heart and heart-lung transplantation: is the timing adequate? Ann Thorac Surg 61: 674-8. https://doi.org/10.1016/0003-4975(95)01059-9

11. PAROLARI A, CAMERA M, ALAMANNI F, NALIATO M, POLVANI GL, AGRIFOGLIO M, BRAMBILLA M, BIANCARDI C, MUSSONI L, BIGLIOLI P, TREMOLI E 2007 Systemic inflammation after on-pump and off-pump coronary bypass surgery: a one-month follow-up. Ann Thorac Surg 84: 823-8. https://doi.org/10.1016/j.athoracsur.2007.04.048

12. HEDMAN A, LARSSON PT, ALAM M, WALLEN NH, NORDLANDER R, SAMAD BA 2007 CRP, IL-6 and endothelin-1 levels in patients undergoing coronary artery bypass grafting. Do preoperative inflammatory parameters predict early graft occlusion and late cardiovascular events? Int J Cardiol 120: 108-14. https://doi.org/10.1016/j.ijcard.2006.09.004

13. STRÜBER M, CREMER JT, GOHRBANDT B, HAGL C, JANKOWSKI M, VÖLKER B, RÜCKOLDT H, MARTIN M, HAVERICH A 1999 Human cytokine responses to coronary artery bypass grafting with and without cardiopulmonary bypass. Ann Thorac Surg 68: 1330-5.

https://doi.org/10.1016/S0003-4975(99)00729-8

14. BACCI MR, MURAD N, BREDA JR, OLIVERIA AV, HERSZKOWICS N, CARDOSO NK, FONSECA FL 2015 Inflammatory biomarker kinetics after mechanical and bioprosthetic valve replacement. Rev Assoc Med Bras 61: 58-60. https://doi.org/10.1590/1806-9282.61.01.058

15. KAWAHITO K, ADACHI H, INO T 2000 Influence of surgical procedures on interleukin- 6 and monocyte chemotactic and activating factor responses: CABG vs. valvular surgery. J Interferon Cytokine Res 20: 1-6. https://doi.org/10.1089/107999000312676

16. HRYNIEWIECKI T, RAWCZYNSKA-ENGLERT I, ABRAMCZUK E, DZIERZANOWSKA D, WOJDA U, LUKASIK B 1996 The role of cytokines in diagnosis of infective endocarditis (In Polish, with English abstract). Kardiologia Polska 45(8): 115118.

17. ALTER P, HOESCHEN J, RITTER M, MAISCH B 2002 Usefulness of cytokines interleukin- 6 and interleukin- $2 R$ concentrations in diagnosing active infective endocarditis involving native valves. Am J Cardiol 89: 1400-4.

https://doi.org/10.1016/S0002-9149(02)02353-6

18. YILMAZ E, USTUNDAG B, SEN Y, AKARSU S, KURT AN, DOGAN Y 2007 The levels of Ghrelin, TNF-a, and IL-6 in children with cyanotic and acyanotic congenital heart disease. Mediators Inflamm 2007:32403. https://doi.org/10.1155/2007/32403
19. MADHOK AB, OJAMAA K, HARIDAS V, PARNELL VA, PAHWA S, CHOWDHURY D 2006 Cytokine response in children undergoing surgery for congenital heart disease. Pediatr Cardiol 27: 408-13. https://doi.org/10.1007/s00246-006-0934-y

20. GESSLER P, PFENNINGER J, PFAMMATTER JP, CARREL T, BAENZIGER O, DAHINDEN C 2003 Plasma levels of interleukin- 8 and expression of interleukin- 8 receptors on circulating neutrophils and monocytes after cardiopulmonary bypass in children. J Thorac Cardiovasc Surg 126: 718-25. https://doi.org/10.1016/S0022-5223(03)00685-8

21. FURUYA Y, SATOH T, KUWANA M 2010 Interleukin-6 as a potential therapeutic target for pulmonary arterial hypertension. Int J Rheumatol Art ID720305. https://doi.org/10.1155/2010/720305

22. GOLEMBESKI SM, WEST J, TADA Y, FAGAN KA 2005 Interleukin- 6 causes mild pulmonary hypertension and augments hypoxia-induced pulmonary hypertension in mice. Chest 128 (Suppl 6): 572S-573S. https://doi.org/10.1378/chest.128.6_suppl.572S-a

23. STEINER MK, SYRKINA OL, KOLLIPUTI N, MARK EJ, HALES CA, WAXMAN AB 2009 Interleukin- 6 overexpression induces pulmonary hypertension. Circ Res 104: 236-44. https://doi.org/10.1161/CIRCRESAHA.108.182014

24. MARUNA P, VOKURKA M, LINDNER J 2011 Plasma hepcidin correlates positively with interleukin- 6 in patients undergoing pulmonary endarterectomy. Physiol Res 60: 493-502.

25. WEN D, ZHOU XL, LI JJ, LUO F, ZHANG L, GAO LG, WANG LP, SONG L, SUN K, ZOU YB, ZHANG CN, HUI RT 2012 Plasma concentrations of interleukin-6, C-reactive protein, tumor necrosis factor-a and matrix metalloproteinase-9 in aortic dissection. Clin Chim Acta 413: 198-202. https://doi.org/10.1016/j.cca.2011.09.029

26. JUVONEN J, SURCEL HM, SATTA J, TEPPO AM, BLOIGU A, SYRJÄLÄ H, AIRAKSINEN J, LEINONEN M, SAIKKU P, JUVONEN T 1997 Elevated circulating levels of inflammatory cytokines in patients with abdominal aortic aneurysm. Arterioscler Thromb Vasc Biol 17: 2843-7.

https://doi.org/10.1161/01.ATV.17.11.2843

27. GABRIEL EA, LOCALI RF, ROMANO CC, DUARTE AJ, PALMA JH, BUFFOLO E 2007 Analysis of the inflammatory response in endovascular treatment of aortic aneurysms. Eur J Cardiothorac Surg 31: 406-12.

https://doi.org/10.1016/j.ejcts.2006.11.053

28. SWARTBOL P, TRUEDSSON L, NORGREN L 1998 Adverse reactions during endovascular treatment of aortic aneurysms may be triggered by interleukin 6 release from the thrombotic content. J Vasc Surg 28: 664-8. https://doi.org/10.1016/S0741-5214(98)70092-8

29. ARTEMIOU P, CHAROKOPOS N, ROUSKA E, SABOL F, CHRYSOGONIDIS I, TSAVDARIDOU V, PASCHALIDIS G 2012 C-reactive protein/interleukin-6 ratio as marker of the size of the uncomplicated thoracic aortic aneurysms. Interact Cardiovasc Thorac Surg 15: 871-7. https://doi.org/10.1093/icvts/ivs331

30. GU J, HU J, ZHANG HW, XIAO ZH, FANG Z, QIAN H, ZHONG MH, GUO YQ, ZHANG EY, SHI YK, MENG W 2015 Time-dependent changes of plasma inflammatory biomarkers in type A aortic dissection patients without optimal medical management. J Cardiothorac Surg 10: 3. https://doi.org/10.1186/s13019014-0199-0

31. CHEUK BL, CHAN YC, CHENG SW 2012 Changes in inflammatory response after endovascular treatment for type B aortic dissection. PLoS One 7: e37389. https://doi.org/10.1371/journal.pone.0037389

32. ACEBO E, VAL-BERNALJF, GOMEZ-ROMAN JJ, REVUELTA JM 2003 Clinicopathologic study and DNA analysis of 37 cardiac myxomas: a 28-year experience. Chest 123: 1379-85. https://doi.org/10.1378/chest.123.5.1379 
33. SOEPARWATA R, POEML P, SCHMID C, NEUHOF H, SCHELD HH 1996 Interleukin-6 plasma levels and tumor size in cardiac myxoma. J Thorac Cardiovasc Surg 112: 1675-7. https://oi.org/10.1016/S0022-5223(96)70031-4

34. EZERIOHA N, FENG W 2015 Intracardiac myxoma, cerebral aneurysms and elevated Interleukin-6. Case Rep Neurol 7: 152-5. https://doi.org/10.1159/000437256

35. YUAN SM 2016 Fever of unknown origin as an initial symptom of cardiac myxoma. Cheng Ching Med J 12: 40-4

36. KUBALA L, CIZ M, VONDRÁCEK J, CERNÝ J, NEMEC P, STUDENÍK P, CIZOVÁ H, LOJEK A 2002 Perioperative and postoperative course of cytokines and the metabolic activity of neutrophils in human cardiac operations and heart transplantation. J Thorac Cardiovasc Surg 124: 1122-9.

https://doi.org/10.1067/mtc.2002.125814

37. FINKEL MS, HOFFMAN RA, SHEN L, ODDIS CV, SIMMONS RL, HATTLER BG 1993 Interleukin-6 (IL-6) as a mediator of stunned myocardium. Am J Cardiol 71: 1231-2. https://doi.org/10.1016/0002-9149(93)90654-U

38. CARUSO R, BOTTA L, VERDE A, MILAZZO F, VECCHI I, TRIVELLA MG, MARTINELLI L, PAINO R, FRIGERIO M, PARODI O 2014 Relationship between pre-implant interleukin-6 levels, inflammatory response, and early outcome in patients supported by left ventricular assist device: a prospective study. PLoS One 9: e90802. https://doi.org/10.1371/journal.pone.0090802

39. GOLDSTEIN DJ, MOAZAMI N, SELDOMRIDGE JA, LAIO H, ASHTON RC Jr, NAKA Y, PINSKY DJ, OZ MC 1997 Circulatory resuscitation with left ventricular assist device support reduces interleukins 6 and 8 levels. Ann Thorac Surg 63: 971-4. https://doi.org/10.1016/S0003-4975(96)01117-4

40. BURZOTTA F, IACOVIELLO L, Di CASTELNUOVO A, GLIECA F, LUCIANI N, ZAMPARELLI R, SCHIAVELLO R, DONATI MB, MASERI A, POSSATI G, ANDREOTTI F 2001 Relation of the $-174 \mathrm{G} / \mathrm{C}$ polymorphism of interleukin- 6 to interleukin- 6 plasma levels and to length of hospitalization after surgical coronary revascularization. Am J Cardiol 88(10): 1125-1128

41. AKER S, BANTIS C, REIS P, KUHR N, SCHWANDT C, GRABENSEE B, HEERING P, IVENS K 2009 Influence of interleukin-6 G-174C gene polymorphism on coronary artery disease, cardiovascular complications and mortality in dialysis patients. Nephrol Dial Transplant 24: 2847-51.

https://doi.org/10.1093/ndt/gfp141
42. KRISTIANSEN OP, MANDRUP-POULSEN T 2005 Interleukin- 6 and diabetes: the good, the bad, or the indifferent? Diabetes 54 Suppl 2: S114-24.

https://doi.org/10.2337/diabetes.54.suppl_2.S114

43. SULEIMAN MS, ZACHAROWSKI K, ANGELINI GD 2008 Inflammatory response and cardioprotection during open-heart surgery: the importance of anaesthetics. Br J Pharmacol 153: 21-33. https://doi.org/10.1038/sj.bjp.0707526

44. ATAN R, CROSBIE DC, BELLOMO R 2013 Techniques of extracorporeal cytokine removal: a systematic review of human studies. Ren Fail 35: 1061-70.

https://doi.org/10.3109/0886022X.2013.815089

45. HSING CH, WANG JJ 2015 Clinical implication of perioperative inflammatory cytokine alteration. Acta Anaesthesiol Taiwan 53: 23-8. https://doi.org/10.1016/j.aat.2015.03.002

46. SHEIKHI MA, EBADI A, SHAHRIARY A, DAVOODZADEH H, RAHMANI H 2015 Cardiac surgery anesthesia and systemic inflammatory response. Int J Bioassays 4: 3648-55. https://doi.org/10.21746/ijbio.2015.02.005

47. HEINZMANN BULOW NM, COLPO E, DUARTE MF, CORREA EFM, SCHLOSSER RS, LAUDA A, KADE IJ, ROCHA JBT 2014 Inflammatory response in patients under coronary artery bypass grafting surgery and clinical implications: a review of the relevance of dexmedetomidine use. ISRN Anesthesiol 2014: ID 905238. https://doi.org/10.1155/2014/905238

48. LEBHERZ C, KAHLES F, PIOTROWSKI K, VOGESER M, FOLDENAUER AC, NASSAU K, KILGER E, MARX N, PARHOFER KG, LEHRKE M 2016 Interleukin-6 predicts inflammation-induced increase of Glucagon-like peptide-1 in humans in response to cardiac surgery with association to parameters of glucose metabolism. Cardiovasc Diabetol 15:21. https://doi.org/10.1186/s12933-016-0330-8

49. ESTEBAN E, FERRER R, ALSINA L, ARTIGAS A 2013 Immunomodulation in sepsis: the role of endotoxin removal by polymyxin B-immobilized cartridge. Mediators Inflamm 2013: 507539. https://doi.org/10.1155/2013/507539

50. BRUENGER F, KIZNER L, WEILE J, MORSHUIS M, GUMMERT JF 2015 First successful combination of ECMO with cytokine removal therapy in cardiogenic septic shock: a case report. Int J Artif Organs 38: 113-6. https://doi.org/10.5301/ijao.5000382 